\title{
MONITORING SURVEY OF NITRATE CONTENT IN BEETROOT, RADISH AND CABBAGE IN POLAND
}

\author{
Joanna Gajda-Wyrębek , Jolanta Jareckal, Marta Dmitruk ${ }^{l}$
}

${ }^{1}$ National Institute of Public Health NIH - National Research Institute, Department of Food Safety, Warsaw, Poland

\begin{abstract}
Background. Nitrates, compounds commonly occurring in nature, are present for example in vegetables, where they accumulate and become their contaminants. It is estimated that approximately $70-90 \%$ of nitrates intake comes from vegetables, which are therefore the main source of human exposure to these compounds through dietary intake. The European Union legislation limits nitrates as contaminants to three leafy vegetables, i.e. lettuce, spinach and rucola. The EU Member States are obliged to monitor nitrate levels in vegetables which may contain significant levels of these compounds.

Objective. To present the results of monitoring surveys on nitrate levels in radish and beetroot as well as in cabbage carried out in Poland between 2012 and 2019.

Material and methods. A total of 966 vegetable samples were tested. Chemical analyses were carried out in accredited laboratories of the State Sanitary Inspection. Analyses were performed by spectrophotometric methods using nitrate reduction on cadmium columns or by HPLC.

Results. The median nitrate content in beetroot was $1,260.0 \mathrm{mg} \mathrm{NO}_{3}^{-} / \mathrm{kg}$, whilst at the 95 th percentile level - 3,222.2 $\mathrm{mg}$ $\mathrm{NO}_{3}^{-} / \mathrm{kg}$. The levels of nitrates in beetroot preserves were lower: $1,030.3 \mathrm{mg} \mathrm{NO}-/ \mathrm{kg}$ (median) and $2337,2 \mathrm{mg} \mathrm{NO}_{3}^{-} / \mathrm{kg}^{-}$ (95th percentile). The median content of nitrates in radish and cabbage was $1,337.0 \mathrm{mg} \mathrm{NO}-\mathrm{kg}_{3}^{-}$and $369,0 \mathrm{mg} \mathrm{NO}-/ \mathrm{kg}^{-}$ respectively, while at the 95 th percentile the content of these compounds was found to be $3,381.5 \mathrm{mg} \mathrm{NO}-\mathrm{kg}_{3}^{-}$and $1545,8 \mathrm{mg}$ $\mathrm{NO}_{3}^{-} / \mathrm{kg}$, respectively.

Conclusions. The nitrate content in radish and cabbage does not pose a risk to the health of consumers, whilst the consumption of beetroot containing significant amounts of the above mentioned compounds may result in exceeding the ADI especially for young children.
\end{abstract}

Key words: monitoring, nitrate content in vegetables, beetroot, radish, cabbage

\section{STRESZCZENIE}

Wprowadzenie. Azotany (V), związki powszechnie występujące w przyrodzie, są obecne m.in. w warzywach, w których się kumulują i stanowią ich zanieczyszczenie. Szacuje się, że około 70 - 90\% spożywanych azotanów (V) pochodzi właśnie z warzyw, które tym samym są głównym źródłem narażenia człowieka na te związki przy pobraniu wraz z dietą. W ustawodawstwie Unii Europejskiej limity azotanów (V) jako zanieczyszczeń dotyczą trzech warzyw liściastych tj. sałaty, szpinaku i rukoli. Państwa należące do UE mają obowiązek monitorowania poziomów azotanów (V) w warzywach mogących zawierać znaczne ilości tych związków.

Cel badań. Celem pracy jest przedstawienie wyników badań monitoringowych w zakresie zawartości azotanów (V) w burakach, rzodkiewce i kapuście w Polsce latach 2012-2019.

Material i metody. Przebadano łącznie 966 próbek buraków, rzodkiewki i kapusty. Wykonawcami badań były akredytowane laboratoria Państwowej Inspekcji Sanitarnej. Analizy wykonywano metodą spektrofotometryczną z użyciem kolumn kadmowych lub metodą HPLC.

Wyniki. Mediana zawartości azotanów (V) w burakach wynosiła 1260,0 $\mathrm{mg} \mathrm{NO}_{3}^{-} / \mathrm{kg}$, natomiast zawartość tych związków na poziomie 95 percentyla - 3222,2 $\mathrm{mg} \mathrm{NO}_{3}^{-} / \mathrm{kg}$. Poziomy azotanów (V) w przetworach z buraków były niższe i wynosiły odpowiednio 1030,3 $\mathrm{mg} \mathrm{NO}_{3}^{-} / \mathrm{kg}$ (mediana) oraz 2337,2 $\mathrm{mg} \mathrm{NO}_{3}^{-} / \mathrm{kg}$ (95 percentyl). Mediana zawartości azotanów (V) w rzodkiewkach oraz kapuście wynosiła $1337,0 \mathrm{mg} \mathrm{NO}_{3}^{-} / \mathrm{kg}$ oraz $369,0 \mathrm{mg} \mathrm{NO}-\mathrm{kg}_{3}^{-}$odpowiednio, natomiast na poziomie 95 percentyla stwierdzono zawartość tych związków na poziomie 3381,5 mg NO $\mathrm{mg}_{3}^{-} / \mathrm{kg}$ oraz $1545,8 \mathrm{mg} \mathrm{\textrm {NO } _ { 3 } ^ { - }} / \mathrm{kg}^{-}$

Wnioski. Zawartość azotanów (V) w rzodkiewce i kapuście nie stanowi zagrożenia dla zdrowia konsumentów, natomiast spożycie buraków zawierających znaczne ilości ww. związków może skutkować przekroczeniem ADI zwłaszcza dla małych dzieci.

Słowa kluczowe: monitoring, zawartość azotanów (V) w warzywach, buraki, rzodkiewka, kapusta

Corresponding author: Joanna Gajda-Wyrębek, National Institute of Public Health NIH - National Research Institute, Department of Food Safety, 24 Chocimska str., 00-791Warsaw, Poland

(C) Copyright by the National Institute of Public Health NIH - National Research Institute 


\section{INTRODUCTION}

Nitrates are naturally occurring chemical compounds and a component of soil and water. They come from the natural decomposition of organic substances, such as plant and animal proteins and animal excretions. This decomposition takes place under the influence of microorganisms and the ammonium ion formed is oxidised to, for example, nitrate. The natural content of nitrates in soil and water, which is approximately $10 \mathrm{mg} / 1$, may be increased as a result of artificial nitrogen fertilisers used in agricultural production, the introduction of excrement from animal breeding into the soil and the release of urban waste into the environment (municipal sewage), industrial waste (fuel refineries) and transport waste (nitrogen oxides from motor vehicles). Nitrates are transferred from soil and water to plants, including vegetables, which can contain tens to thousands of $\mathrm{mg} / \mathrm{kg}$ of these compounds. The amount of nitrates in vegetables depends on the season in which the vegetables are grown, soil moisture, access to light, temperature, use of fertilisers, and storage of crops.

In 2008, the European Food Safety Authority (EFSA) assessed the risk of consuming vegetables containing nitrates [5]. Vegetables contain more nitrates than other foods and are the main source of human exposure to these compounds through dietary intake. It is estimated that around $70-90 \%$ of nitrate intake comes from vegetables. Nitrates are present in vegetables in varying amounts, but when assessing consumer intake of nitrates, it is not just the quantity of vegetables consumed that is important, but also their type. Green leafy vegetables such as spinach, lettuce and rucola contain the highest levels of nitrates, while vegetables whose edible parts are the storage organs of the plant, e.g. carrots, potatoes, leeks, onions, tomatoes, cucumbers, peas and beans, have relatively low levels of these compounds. Technological processes such as washing, cooking, grilling and deep frying have a statistically significant effect on reducing the nitrate content in vegetables.

Nitrates are compounds of low toxicity. However, the compounds formed as a result of nitrate reduction and the products of nitrate metabolism, i.e. nitrites, nitrogen oxides and $\mathrm{N}$-nitroso compounds, have a negative impact on health. Harmful effects of nitrites (and indirectly of nitrates, which are reduced to nitrites) on the body include oxidation of haemoglobin to methaemoglobin, disruption of the processes of digestion of carbohydrates and fats, impaired utilisation of B vitamins, or reduced levels of vitamin A and carotenoides. Nitrites and indirectly nitrates are precursors of N-nitroso compounds with proven carcinogenic effects. Nitrosation reactions can occur both in foodstuffs and in the human body. The stomach's acidic environment promotes the nitrosation reaction. Infants and babies are particularly vulnerable to the harmful effects of nitrites and indirectly of nitrates, as they have no mechanism developed for converting the methaemoglobin formed by the action of nitrites into oxyhaemoglobin.

It should be underlined that EFSA concluded in its opinion of 2008 that estimated human exposure to nitrate in vegetables does not pose a significant risk to consumer health. The benefits of eating vegetables outweigh the risks associated with the intake of nitrates contained in these vegetables.

Nitrates present in food may be both a contaminant (resulting from agricultural practices and from industrial and automotive sectors) and be intentionally added as additives (preservatives) in the manufacturing of certain foodstuffs. In 2017, as part of the re-evaluation programme on the safety of food additives, EFSA issued an opinion on the safety of using nitrates as additives (E 251 sodium nitrate and E 252 potassium nitrate) [6]. For nitrate, the current acceptable daily intake (ADI) of $3.7 \mathrm{mg} \mathrm{NO}_{3}^{-} / \mathrm{kg}$ body weight/day was maintained, corresponding to $222 \mathrm{mg}$ $\mathrm{NO}_{3}^{-} /$day for an adult of $60 \mathrm{~kg}$.

The limits for nitrate as a contaminant in food are set by Commission Regulation (EC) No 1881/2006 of 19 December 2006 setting maximum levels for certain contaminants in foodstuffs (as amended by Regulation (EU) No 1258/2011) [1, 3]. In this document, the maximum levels for nitrate are set for vegetables that accumulate significant amounts of this contaminant, i.e. spinach, lettuce and rucola. The latter vegetable accumulates extremely high levels of nitrate, which is why the limit for this compound is as high as $7000 \mathrm{mg}$ $\mathrm{NO}_{3}^{-} / \mathrm{kg}$. In addition, according to the aforementioned Regulation, nitrates are limited in processed cerealbased foods and baby foods for infants and young children.

It should be noted that the requirements for nitrate limits in vegetables, which existed in national legislation before Poland's accession to the European Union, covered a much wider range of vegetables. In the Regulation of the Polish Minister of Health of 13 January 2003 [7], vegetables were divided into six groups according to the degree of nitrate accumulation. In addition to lettuce and spinach, the legislation in force at the time also included: radish, beetroot, turnip, kohlrabi, dill, cabbage, chives, kale, green beans, carrot, parsley, garlic, cucumber, cauliflower, leek, celery, broccoli, tomato, potato, onion, pepper, rhubarb, beans (dry beans). The seventh group consisted of vegetables and potatoes for infants and young children. The acceptable level of nitrates in the above vegetables ranged from 200 to $4,500 \mathrm{mg}$ $\mathrm{NO}_{3}^{-} / \mathrm{kg}$. 
Article 9 of Commission Regulation (EC) No 1881/2006 [1] obliges EU Member States to monitor nitrate levels in vegetables which may contain significant levels, in particular green leafy vegetables. The results of these studies should be regularly reported to EFSA.

\section{MATERIAL AND METHODS}

Monitoring surveys to determine nitrate levels in radish and beetroot (2012-2013) as well as in cabbage (2014-2019) were carried out in Poland between 2012 and 2019. These vegetables are widely eaten by the Polish consumer. 966 samples were tested.

Sampling and chemical analyses were carried out by employees of the State Sanitary Inspection nationwide. Samples for testing the content of nitrate as a contaminant were taken according to the procedure described in Commission Regulation (EC) No 1882/2006 of 19 December 2006 laying down methods of sampling and analysis for the official control of the levels of nitrates in certain foodstuffs [2]. Domestic and imported vegetables were sampled for testing, in the case of imported vegetables, no more than $20 \%$ of the samples taken. Imported vegetables were taken when available in the market.

Laboratory-validated and accredited analytical methods were used for the determinations, meeting the requirements of the performance criteria set out in Commission Regulation (EC) No 1882/2006 [2]. Analyses of the nitrate content of the vegetable samples were mostly performed by spectrophotometric methods using nitrate reduction on cadmium columns. In addition, some laboratories of sanitary and epidemiological stations determined nitrates by HPLC.

This paper addresses the results of monitoring studies of nitrate content in selected vegetables (radish, beetroot, cabbage) carried out in Poland over the period 2012-2019. The results obtained will provide a basis for assessing the extent of nitrate intake with vegetables by Polish consumers. It should be noted that in 2010 National Institute of Public Health - National Institute of Hygiene estimated the intake of nitrates through the diet in Poland [4]. The intake of these compounds with vegetables in Poland was more than half lower than that presented in the EFSA opinion of 2008 for the average EU consumer. The reason for the lower than average intake of nitrates with vegetables in Poland may be the lower consumption of vegetables in our country (about half of the value adopted for the EU in 2008) and a different profile of vegetable consumption - the Polish diet is dominated by potatoes, cabbage, beetroot, carrots and tomatoes.

\section{RESULT AND DISCUSSION}

\section{Nitrate content in beetroot}

The nitrate content in the beetroot is shown in Table 1. In 2012-2013, the nitrate content in 175 samples of fresh and frozen beetroot and 50 samples of preserved beetroot was tested. Beetroot preserves included products such as boiled beetroot, pasteurised beetroot, sliced beetroot in vinegar marinade, grated beetroot (with vinegar and spices) and pickled beetroot.

Table 1. Nitrate content in beetroot (tested in 2012-2013)

\begin{tabular}{|c|c|c|}
\hline \multicolumn{3}{|c|}{ Nitrate content $\left[\mathrm{mg} \mathrm{NO}_{3}^{-} / \mathrm{kg}\right]$} \\
\hline & $\begin{array}{c}\text { Fresh and } \\
\text { frozen } \\
\text { beetroot }\end{array}$ & $\begin{array}{c}\text { Beetroot } \\
\text { preserves }\end{array}$ \\
\hline Number of samples & 175 & 50 \\
\hline Mean & $1,420.1$ & $1,151.0$ \\
\hline Median & $1,260.0$ & $1,030.3$ \\
\hline 95th percentile & $3,222.2$ & $2,337.2$ \\
\hline Maximum value & $7,330.0$ & $3,066.0$ \\
\hline
\end{tabular}

The median nitrate content in beetroot was $1,260.0$ $\mathrm{mg} \mathrm{NO}_{3}^{-} / \mathrm{kg}$, while that in beetroot preserves was lower at $1,030.3 \mathrm{mg} \mathrm{NO}-\mathrm{kg}$. A similar correlation between nitrate content in beetroot and beetroot preserves can be observed at the 95th percentile level - nitrate content in beetroot was $3,222.2 \mathrm{mg} \mathrm{NO}-/ \mathrm{kg}$ and in beetroot preserves it was almost $1,000 \mathrm{mg} / \mathrm{kg}$ lower the calculated value was $2,337.2 \mathrm{mg} \mathrm{NO}_{3}^{-} / \mathrm{kg}$. The fact that the nitrate contents found in beetroot preserves are lower than in fresh beetroot can be explained by the fact that the application of technological processes such as washing, peeling, cooking affects the reduction of nitrate content in vegetables [5].

Assessing the median value of nitrate content in beetroot, it should be stated that both values, i.e. for both fresh beetroot and beetroot preserves, are lower than the maximum permissible level of nitrate specified for beetroot in the Regulation of the Minister of Health of 2003 [7]. The nitrate limit for beetroot specified in the above-mentioned Regulation was $1,500 \mathrm{mg} \mathrm{NO}_{3}^{-} / \mathrm{kg}$.

The EFSA opinion of 2017 [6] concluded that root and tuberous vegetables were the main source of nitrates in the diet of infants and young children. For this reason, it is of concern that beetroot samples at the 95th percentile level had 2.5 times higher nitrate content than the median, and the maximum value was almost six times higher than the median. Therefore, the possibility cannot be excluded that a beetroot dish containing very high levels of nitrates may be served to young children (under 3 years of age), which may lead to the ADI for these compounds being exceeded. For 
example, the ingestion of $50 \mathrm{~g}$ of beetroot with a nitrate content of $3,000 \mathrm{mg} \mathrm{NO}_{3}^{-} / \mathrm{kg}$ by a child weighing $12 \mathrm{~kg}$ will more than triple the ADI for these compounds (the ingestion of nitrate with beetroot in this case would be $337.8 \%$ of the ADI). It is also important to remember that nitrates are also consumed with other components of the diet, such as other vegetables, meat products or water.

On the basis of the results presented herein, it can be concluded that beetroot is a vegetable with a high nitrate accumulation and its consumption may cause the ADI for this compound to be exceeded. It is therefore important to keep nitrate levels in beetroot as low as possible. Setting legal limits on the content of these compounds in beetroot would allow these vegetables to be included in official food control plans. Regular testing of even a small number of samples of beetroot by the official food control authorities, and the consequent threat of withdrawal of products from the market if the nitrate content is exceeded, would draw the attention of manufacturers to the issue of these compounds in beetroot. This could result in particular efforts being made to apply the principles of good agricultural practice when growing this vegetable in order to keep nitrate levels as low as possible.

\section{Nitrate content in radish}

The nitrate content in the radish is shown in Table 2. The nitrate content in 149 radish samples was tested over the period 2012-2013.

Table 2. Nitrate content in radish (tested in 2012-2013)

\begin{tabular}{|c|c|}
\hline \multicolumn{2}{|c|}{ Nitrate content $\left[\mathrm{mg} \mathrm{NO}_{3}^{-} / \mathrm{kg}\right]$} \\
\hline Number of samples & 149 \\
\hline Mean & $1,531.6$ \\
\hline Median & $1,337.0$ \\
\hline 95th percentile & $3,381.5$ \\
\hline Maximum value & $9,921.0$ \\
\hline
\end{tabular}

The median content of nitrate in radish was 1,337.0 mg $\mathrm{NO}_{3}^{-} / \mathrm{kg}$, while at the 95 th percentile level the content of these compounds was found to be 3,381.5 $\mathrm{mg} \mathrm{NO}_{3}^{-} / \mathrm{kg}$. In the Regulation of the Minister of Health of 2003 [7], radish was in the same group as beetroot and therefore the limit for nitrate in radish was 1,500 $\mathrm{mg} \mathrm{NO}=3 / \mathrm{kg}$, similar to that for beetroot. The median content of nitrates calculated for the radish samples included herein is below the limit of these compounds set for this vegetable in the aforementioned Regulation of the Minister of Health.

The nitrate content at the 95th percentile level is 2.5 times higher than the median value. However, the radish is one of the vegetables consumed in small quantities, mainly in spring in the form of spring vegetables. It is also not a vegetable that forms a significant part of a young children's diet - it is mainly eaten as an addition to sandwiches or salads. It can therefore be concluded that the nitrate content of radish does not pose a health risk to consumers, including young children, despite the fact that this is a vegetable with a high nitrate accumulation rate.

\section{Nitrate content in cabbage}

The nitrate content in cabbage is shown in Table 3. The nitrate content in 592 cabbage samples was tested over the period 2014-2019.

Table 3. Nitrate content in cabbage (tested in 2014-2019)

\begin{tabular}{|c|c|}
\hline \multicolumn{2}{|c|}{ Nitrate content $\left[\mathrm{mg} \mathrm{NO}_{3}^{-} / \mathrm{kg}\right]$} \\
\hline Number of samples & 592 \\
\hline Mean & 538.7 \\
\hline Median & 369.0 \\
\hline 95th percentile & $1,545.8$ \\
\hline Maximum value & $3,400.1$ \\
\hline
\end{tabular}

The median content of nitrate in cabbage was 369.0 $\mathrm{mg} \mathrm{NO}_{3}^{-} / \mathrm{kg}$, while at the 95th percentile level the content of these compounds was found to be 1,545.8 $\mathrm{mg} \mathrm{NO}=3$. The limit for nitrate in cabbage provided for in the Regulation of the Polish Minister of Health of 2003 [7] was $750 \mathrm{mg} \mathrm{NO}_{3}^{-} / \mathrm{kg}$, so it is a vegetable that accumulates less of these compounds than beetroot or radish. However, cabbage is a popular vegetable in Poland, consumed frequently (especially in autumn and winter), and may therefore be a significant source of nitrates in the Polish diet. The median value of nitrate content in cabbage is almost half of the permissible content of these compounds set for this vegetable in the Regulation of the Minister of Health of 2003 [7]. The nitrate content at the 95th percentile level is 4 times higher than the median value.

The consumption of $200 \mathrm{~g}$ of cabbage containing $1,500 \mathrm{mg} \mathrm{NO}_{3}^{-} / \mathrm{kg}$ (a value close to the 95 th percentile level) by a $60 \mathrm{~kg}$ adult will result in an excess of the ADI (135\% of the ADI), while the consumption of cabbage with an average nitrate content - the median value - results in an intake of these compounds of $33.2 \%$ of the ADI. This shows that the nitrate content in cabbage does not pose a risk to consumer health, despite the fact that the vegetable is an important part of the Polish diet.

\section{SUMMARY}

According to the EFSA assessment, vegetables and vegetable-based products are the main source 
of nitrate intake from the diet [5]. The total dietary intake of nitrates in Poland did not exceed the ADI for these compounds for adults weighing $60 \mathrm{~kg}$ [4]. However, for children, who are of lower body weight than adults, the consumption of vegetables with high nitrate content, such as beetroot, may cause the ADI to be exceeded. Although the benefits of eating vegetables outweigh the risks associated with the intake of nitrate contained in these vegetables [5], by properly designing the diet (e.g. ensuring a variety of vegetables consumed), one can have an impact on minimising the risk of exceeding the ADI for nitrate.

\section{CONCLUSIONS}

Beetroot, radish and to a lesser extent cabbage are vegetables that accumulate significant amounts of nitrates.

The median content of nitrates in all the above vegetables was lower than the permissible content of these compounds set for individual vegetables in the Regulation of the Polish Minister of Health of 2003. This shows that, in general, good agricultural practice is applied in vegetable cultivation, which prevents excessive accumulation of nitrates in the above vegetables.

Particular attention should be paid to the nitrate content in the beetroot. The consumption of this vegetable containing significant amounts of the above mentioned compounds may result in exceeding the ADI especially for young children. It is advisable to consider setting a limit on the nitrate content in this vegetable, and this would allow these vegetables to be included in official food control plans.

The nitrate content in radish and cabbage does not pose a risk to the health of consumers.

\section{Acknowledgements}

This work was financially supported by the National Institute of Public Health NIH - National Research Institute in Warsaw, Poland in the frame of projects: $3 /$ ZŚ.1/2018, BŻ-3/2019, BŻ-4/2020 (FB-4/2020).

\section{Conflict of interest}

The Authors declare no conflict of interest.

\section{REFERENCES}

1. Commission Regulation (EC) No 1881/2006 of 19 December 2006 setting maximum levels for certain contaminants in foodstuffs. Official Journal EU L 364 of 20 December 2006, p. 5.

2. Commission Regulation (EC) No $1882 / 2006$ of 19 December 2006 laying down methods of sampling and analysis for the official control of the levels of nitrates in certain foodstuffs. Official Journal EU L 364 of 20 December 2006, p. 25.

3. Commission Regulation (EU) No 1258/2011 of 2 December 2011 amending Regulation (EC) No $1881 / 2006$ as regards maximum levels for nitrates in foodstuffs. Official Journal EU L 320/15 of 03 December 2011.

4. Gajda-Wyrębek J., Jarecka J., Kuźma K., Beresińska M., Karłowski K.: Zawartość azotanów (V) w sałacie $\mathrm{i}$ szpinaku. [Content of nitrates in lettuce and spinach]. In: Karłowski K., Rybińska K., Postupolski $J$. (ed.): Ocena narażenia konsumentów na chemiczne i mikrobiologiczne zanieczyszczenia żywności programy realizowane w latach 2004-2008. [Assessment of consumer exposure to chemical and microbiological food contaminants - 2004-2008 programmes]. National Institute of Public Health - National Institute of Hygiene, Warsaw 2010, 85-98, ISBN 03-89379-18-X.

5. Opinion of the Scientific Panel on Contaminants in the Food chain on a request from the European Commission to perform a scientific risk assessment on nitrate in vegetables. The EFSA Journal 2008;689:1-79.

6. Re-evaluation of sodium nitrate (E 251) and potassium nitrate (E 252) as food additives. The EFSA Journal 2017;15(6):4787.

7. Rozporządzenie Ministra Zdrowia $\mathrm{z}$ dnia 13 stycznia 2003 roku w sprawie maksymalnych poziomów zanieczyszczeń chemicznych i biologicznych, które mogą znajdować się w żywności, składnikach żywności, dozwolonych substancjach dodatkowych, substancjach pomagających w przetwarzaniu albo na powierzchni żywności. Dz. U. No 37 of 4 March 2003, item 326 (in Polish).

Received: 30.06 .2021

Accepted: 03.08.2021

Published online first: 11.08.2021 